\title{
THE ROLE OF "FOLK CRAFT" SCIENCE IN IMPROVING THE LIVING CULTURE AND SPIRITUALITY OF THE PEOPLE
}

\author{
Madina B. Akobirova \\ Bukhara State University, Uzbekistan \\ Shahida K. Islamova \\ 3 Rd Year Student Bukhara State University, Uzbekistan \\ Dilafruz A. Sayfullayeva \\ Bukhara State University, Uzbekistan \\ Sadoqat T. Navruzova \\ 2 Rd Year Student Bukhara State University, Uzbekistan
}

\section{ABSTRACT}

In this article, the role of "folk art" as one of the specialty disciplines for students in the direction of "technological education" in raising the life culture and spirituality of the people, types of Uzbek folk art, stages of history and development of Applied Art, types, history and technology of weaving, carpet weaving, decorative art are highlighted.

KEYWORDS: - Educational institutions, motivation, cultural heritage, Folk Crafts, ancient monuments, decoration, dashing, carpet weaving, miniature, bluish-lozhuward, painter, wet-pattern, mosaic, lavh, papemashe, intellectual, architecture.

\section{INTRODUCTION}

Patterns and paintings, which are the alphabet of applied decorative art, are one of the oldest forms of folk applied art. The yellow ornaments of man-made masterpieces are used not only in all kinds of applied arts, but also in the architectural decoration of buildings and structures.
The history of patterns is extremely ancient, along with the artistic culture of mankind. Before the writing came into being, the sketch served as a writing. In the process of cultural development, he distinguished himself from painting. Archaeological sources also indicate that the pattern has existed since ancient times in all peoples of the world. Metal, pottery, pottery, weapons, decorated with geometric shapes in the Paleolithic and Neolithic periods, and floral 
CURRENT RESEARCH JOURNAL OF PEDAGOGICS 2(12): 135-139,

December 2021 DOI: https://doi.org/10.37547/pedagogics-crjp-02-12-27

ISSN 2767-3278

(C)2021 Master Journals

Crossref do: 81 Google

Accepted 21 $1^{\text {th }}$ December, 2021 \& Published $26^{\text {th }}$ December, 2021

(Islamic) patterns in Mycenaean art, ancient Iran, China and India, along with geometric shapes. The symbolic elements in the patterns were formed and developed under the influence of different countries, the geographical environment of the peoples, the flora and fauna of the country, the culture.

The most attractive and high-rise of the pattern coincides with the Renaissance. Beginning in the late 19 th century, various trends emerged during this period, greatly reducing the use of patterns and even abandoning them altogether.

Painting is one of the main and ancient forms of folk decorative art. Architectural monuments and archeological finds in Central Asia testify to the ancient development of this art in our country. The development of such professions as architecture, pottery, jewelry, plumbing, embroidery, etc., depends on the development of the art of painting. The high spirituality of our ancestors can be seen in the attractiveness of the patterns found in the Castle, Tuprakkala, ancient Urgench, ancient Termez, Ayritom, Varakhsha, Afrosiyab and other places.

\section{THE MAIN FINDINGS AND RESULTS}

Pattern art is one of the oldest in the history of Central Asian culture and is notable for its unique patterns. The most common patterns in Central Asia are of two types: geometric lines and intricate shapes are called girths. The most common type of floral pattern is called Islamic. The skill and high skill of the painter ensures the melody of the exact size elements, the balance of tastefully selected colors. The oldest examples of Central Asian patterns can be found mainly in architectural monuments and buildings. The most beautiful patterns are made of plaster, wood and stone carvings, painted wood (columns, beads, vases, etc.). Even in the unique examples of ancient jewelry that have come down to us, it is astonishing that the ornaments created by our ancestors with delicate taste, skillful hands and deep intellect were made in the perfect solutions of those species. For example, the golden zircon (3rd century BC) found in Dalvarzintepa has a compact circular (cylindrical) surface with a simple four-leaf floral pattern in a very rhythmically proportioned manner.

Architecture has been highly developed in our country since ancient times. Examples of this are our historical monuments, mosques and mausoleums. These buildings show the high level of taste, worldview, education and construction culture of our ancestors. In the Uzbek land, the harmoniously developed and historically invaluable works of art created by our ancestors are among the masterpieces of world culture. Masterpieces created by masters of handicrafts give people an aesthetic pleasure. The monuments are decorated with sun-kissed tiles, and the delicate patterns fascinate the involuntary. Although these patterns were created centuries ago, they have not lost their elegance. We can cite the architectural monuments of Samarkand. Invented by ordinary people in stone, pottery and materials, these monumental buildings amaze people with their elegance and majesty. The masters who created them, thanks to their high knowledge and skills, created immortal works and sealed them with stones, which have not lost their value even today.

Since gaining independence, Uzbekistan has opened the way for painting, decorative ornaments, wood carvings and other arts. Representatives of the industry are being rewarded under various conditions. Our President also supports and supports young professionals in the field of art.

At the initiative of the first President of the Republic of Uzbekistan, a special production association was established under the Ministry of 
CURRENT RESEARCH JOURNAL OF PEDAGOGICS 2(12): 135-139,

December 2021 DOI: https://doi.org/10.37547/pedagogics-crjp-02-12-27

ISSN 2767-3278

(C)2021 Master Journals

Crossref do: 81 Google

Accepted 21 $1^{\text {th }}$ December, 2021 \& Published $26^{\text {th }}$ December, 2021

Culture on the basis of organizations and enterprises in the field of applied arts, painting and design. The Kamoliddin Behzod State Prize has been established for the best works in order to provide them with material and moral incentives.

Such high awards are established and the masters are honored not only in the field in which they work. Among them are handicrafts, pottery, tiling, painting, bricklaying, and many others, which have been developing our national handicrafts as a father's profession for generations. These professions are distinguished from other professions by the fact that these professions, which were practiced by our ancestors for a long time, are very laborious, elegant and time-consuming.

The national embroidery of Uzbekistan complements the interior of the house in a unique way, along with architectural decoration. For many centuries in Bukhara, Urgut, Fergana, Kokand, Andijan, Samarkand, Tashkent, Namangan, Piskent there were large centers of local art style and embroidery.

Embroiderers spend a lot of time and effort sewing needles on large fabrics. Embroidery is a poetic reflection of the beauty of nature and the world around it. Large decorative items - suzana, palak, flower bed, bedspread (curtain), shelf, brick, zardevor, bedclothes, ruyjo, etc. doyra, topbarggul (pattern whirlpool), delicate embroidered with images of flowers, leaves, birds, animals. The tradition of handembroidered decorative embroidery lives and develops in Urgut, Kokand, Bukhara, Tashkent and Karakalpakstan.

Carpet weaving and shawl weaving are one of the oldest types of textiles in Uzbekistan. They are divided into three types - short-haired carpets, long-haired carpets - julhirs and bald carpets (sholcha). This type of textile uses spun wool, cotton yarn and silk. Short-haired carpets are woven in the Fergana Valley, Kashkadarya, Jizzakh, Khorezm regions and Karakalpakstan. This rug is given in a reddish-brown harmony and is decorated with colorful details in the form of handicrafts and Islamic. These rugs are characterized by simplicity and clarity of colors.

\section{Conclusion}

The folk arts and crafts of Uzbekistan are constantly being revived, rapidly developing and growing. The number of folk masters working in the republic is growing, folk art includes embroidery, carpet weaving, bucket weaving, knife-making, basket weaving, jewelry, plaster and wood carving and painting, lacquer and paper miniatures. , pottery, etc. This is evidenced by the increasing number of species. This is evidence of the fact that during the period of independence, our country has created more favorable conditions for the development of culture and art, the intellectual and moral development of the people.

\section{REFERENCES}

1. Sayfullayeva D.A Innovative and Individual Approach in Professional and Vocational Training of Young People with Disabilities. Eastern European Scientific Journal. Ausgabe 6- 2017 Part I.- P.154-157

2. Djalolova D.F. Promotion of practical trainings for the development of the creative abilities of students in special subjects using foreign methods of foreign education method. European journal of Research and Reflection in Educational Sciences. Vol.8, No.11, 2020. ISSN 20565852. P 73-79. www.idpublications.org

$\begin{array}{llr}\text { 3. Сайфуллаева } & \text { Д.А } & \text { Методы } \\ \text { математического } & \text { описания } & \text { контуров }\end{array}$


CURRENT RESEARCH JOURNAL OF PEDAGOGICS 2(12): 135-139,

December 2021 DOI: https://doi.org/10.37547/pedagogics-crjp-02-12-27

ISSN 2767-3278

(C)2021 Master Journals

Crossref do: 81 Google

Accepted 21 ${ }^{\text {th }}$ December, 2021 \& Published 26 ${ }^{\text {th }}$ December, 2021

лекал швейных изделий, методи линейно-круговой

аппроксимации.Молодой Учёный

международный научный журнал.2016.№11 часть IV.-Б.459-461

4. Dilafruz Ahmadovna Sayfullayeva. "Methodology of using innovative technologies in technical institutions". PSYCHOLOGY AND EDUCATION. Scopus International Journal.(2021) 58(1)

5. Сайфуллаева Д.А Пути повышения эффективности преподавания специальных дисциплин. International conferenceon science and education.Turkey.-2021. B.72-74

6. SayfullayevaD.A, Rustamov E.T, Rayimova D.D, Jabborova M. J., Faridov M. F. CHARACTERISTICS OF TECHNICAL CREATIVITY IN TECHNOLOGICAL EDUCATION. Innovative technologica methodical research journal.2021.B-37-41

7. Sayfullayeva D.A., Juraev A.R., Toshev Yu.N. Innovative project of preparation of students for professional activity // Научно-методический журнал вестник науки и образования № 19 (97). Часть 2. 2020.C.48

8. А.Р.Жўраев, Д.А. Сайфуллаева, Ш.Бахронова Замонавий таълим технологиялар асосида ташкил қилинадиган шахсга йўналтирилган таълим жараёни // Science and Education. № 2020.Б.169-176

9. Olimov Kakhramon Tanzilovich, Sayfullaeva Dilafruz Ahmedovna, Khimmataliev Dustnazar Omonovich, Ashurova Sanobar Yuldashevna, Gaffarov Feruz Hasanovich.Teaching Special Subjects for Students with Disabilities in Preparation for the Profession by Using Innovative Educational Technologies.
International Journal of Innovative Technology and Exploring Engineering (IJITEE) ISSN: 2278-3075, Volume-9 Issue1S, November 2019.B.425-429

10. Dilafruz Ahmadovna Sayfullayeva, Kakhkhorov Sobir Kh., Bahronova Sh.I.INCREASING THE.PROFESSIONAL CREATIVITY OF STUDENTS IN TEACHING.SPECIALTIES. Проблемы современной науки и образования НАУЧНО-МЕТОДИЧЕСКИЙ ЖУРНАЛ. 2020. № 12 (157). Часть 2 С.33

11. Sayfullayeva D.A., Mirdjanova N.N., Saidova Z.Kh. Развитие профессиональных компетенций и творческих способностей студентов высших учебных заведений // Научнометодический журнал вестник науки и образования № 2020.19 (97). Часть 2.C.55

12. Сайфуллаева ДА,

М.Б.Тошпулатова.Предпосылки

машинного проектирования и разверток деталей одежды с использованием ЭВМ. Наука, техника и образование Научно-методический журнал. - Москва, 2016. № 2 С. 72-75

13. Сайфуллаева Д.А Пути повышения эффективности преподавания специальных дисциплин. International conferenceon science and education.Turkey.-2021. B.72-74

14. SayfullayevaD.A, Rustamov E.T, Rayimova D.D, Jabborova M. J., Faridov M. F. CHARACTERISTICS OF TECHNICAL CREATIVITY IN TECHNOLOGICAL EDUCATION. Innovative technologica methodical research journal.2021.B-37-41

15. Акобирова Мадина Бурановна. Требования, предъявляемые к видам обеспечения САПР швейных изделий. 
CURRENT RESEARCH JOURNAL OF PEDAGOGICS 2(12): 135-139,

December 2021 DOI: https://doi.org/10.37547/pedagogics-crjp-02-12-27

ISSN 2767-3278

(C)2021 Master Journals

Crossref doi) 81 Google

Accepted 21 ${ }^{\text {th }}$ December, $2021 \&$ Published 26 ${ }^{\text {th }}$ December, 2021

Вопросы науки и образования № 6 (7), Москва 2017. Стр 28-29

16. Акобирова Мадина Бурановна, Ахророва Мехринисо Виды используемых прибавок и припусков в одежде. Сборник статей XVIII международной научно-практической конференции "WORLD SCIENCE: PROBLEMS AND INNOVATIONS". 2018.Пенза, Часть 1. C. 47-50

17. Акобирова Мадина Бурановна, Зиедуллоев Нодир Уткирович Методы изготовления лекал одежды. Сборник статей XVIII международной научнопрактической конференции "WORLD SCIENCE: PROBLEMS AND INNOVATIONS".2018.Пенза, Часть 1. С. $51-54$ 